\title{
Stimulation of progesterone secretion by cultured human granulosa cells with melatonin and catecholamines
}

\author{
G. E. Webley, M. R. Luck* and J. P. Hearn \\ MRC/AFRC Comparative Physiology Research Group. Institute of Zoology, Regent's Park, \\ London NWI 4RY, U.K.; and *Institute of Hormone and Fertility Research, Grandweg 64, \\ 2000 Hamburg 54, F.R.G.
}

\begin{abstract}
Summary. Granulosa cells, aspirated from the follicles of patients undergoing treatment for in-vitro fertilization, were cultured in serum-supplemented medium. Adrenaline and noradrenaline stimulated a dose-related increase in progesterone secretion with a maximum stimulation at $10^{-5} \mathrm{M}$, a response that was prevented by the $\beta$-antagonist, propranolol. Adrenaline and hCG showed similar characteristics in their stimulation of progesterone secretion but there was no further increase in progesterone when the 2 compounds were added together. Melatonin stimulated progesterone secretion and, like adrenaline, this stimulation was prevented by propranolol. The ability of both adrenaline and melatonin to increase progesterone secretion was dependent on the degree of follicular development, as determined by peripheral oestradiol concentrations, on the day of laparoscopy. These results suggest that adrenaline and melatonin may have a physiological role in modulating luteal function and that melatonin may act by a $\beta$-adrenergic-related mechanism.
\end{abstract}

Keywords: human; granulosa cells; progesterone secretion; melatonin; catecholamines

\section{Introduction}

There is now substantial evidence that the primate corpus luteum (CL) requires the luteotrophic support provided by pituitary LH (Knobil, 1973; Ross, 1979; Fraser et al., 1985, 1986). Of less certainty is the role of other hormones which can influence progesterone secretion, either directly or by influencing the actions of known luteotrophic or luteolytic agents, and which may have an important modulating effect on CL function.

These potentially modulatory hormones include melatonin and catecholamines. We have described the ability of melatonin to stimulate progesterone production by human granulosa cells in culture (Webley \& Luck, 1986) and by the CL of the marmoset monkey perfused in vivo (Webley \& Hearn, 1987; Hearn \& Webley, 1987).

Catecholamines stimulate progesterone production by the ovary in vivo and by CL tissue and granulosa cells in vitro in a number of species, including the rat (Ratner et al., 1980; Norjavaara et al., 1982), sheep (Jordan et al., 1978), cow (Condon \& Black, 1976; Battista et al., 1987; Luck \& Jungclas, 1987, 1988) and cat (Wheeler et al., 1987). It is, however, uncertain whether catecholamines stimulate steroidogenesis in primate CL. In man, adrenaline and noradrenaline have no effect on progesterone secretion by dispersed luteal cells either in short-term incubation or monolayer culture (Richardson \& Masson, 1980; Casper \& Cotterell, 1984). In the rhesus monkey, catecholamines do not influence cAMP production by homogenates of luteal tissue (Eyster \& Stouffer, 1985), although Bennegard et al. (1984) have demonstrated the ability of noradrenaline to stimulate progesterone secretion by incubated pieces of human $\mathrm{CL}$, and have postulated a role for catecholamines in determining the life-span of the CL. These authors suggest that the innervation 
of blood vessels in the ovary, with the release of noradrenaline, is necessary for the luteolytic action of prostaglandin F-2 $\alpha$. We have tested the hypothesis that adrenaline and noradrenaline act on the human ovary by studying the response of human granulosa cells cultured in vitro.

\section{Materials and Methods}

Cell preparation. Granulosa cells were aspirated from multiple preovulatory follicles of women undergoing in-vitro fertilization. The cells used in the present study were from 15 patients in two clinics, The Humana Hospital Wellington, London, U.K., and the Gemeinschaftspraxis Leidenberger \& Ptnrs, Hamburg, F.R.G. Multiple follicular development was achieved by stimulation with clomiphene citrate and $\mathrm{hMG}$. The regimen was similar in the two clinics, achieving a pregnancy rate of up to $30 \%$, and has been described previously for the patients in Hamburg (Webley \& Luck, 1986). In the Humana Hospital patients received clomiphene $(100 \mathrm{mg} /$ day) on Days 2-6 of the cycle and Pergonal on Days 2, 4, 6, 8, and 10 or on Days 5-11 of the cycle. Follicular development was monitored by serum oestradiol concentrations and/or ultrasonography. The patients in both clinics received 5000 i.u. hCG and the follicles were aspirated by laparoscopy $36 \mathrm{~h}$ later.

Granulosa cells were recovered from follicular fluid after centrifugation at $250 \mathrm{~g}$ for $10 \mathrm{~min}$. The cells from a single patient were suspended in 20-30 ml phosphate-buffered saline (PBS) (Flow Laboratories, Rickmansworth, Herts, U.K.), filtered through a sterile nylon mesh to remove any clumps and separated from erythrocytes on Percoll (Pharmacia, Milton Keynes, Bucks, U.K.) (Webley \& Luck, 1986). In brief, the cell suspension was divided between two siliconized glass round-bottom tubes and underlayered with $60 \%$ Percoll. The tubes were centrifuged at $1000 \mathrm{~g}$ for $20 \mathrm{~min}$ (no brake) and the white cell layer, at the medium-Percoll interface, was carefully removed, resuspended in PBS and washed three times. After the final centrifugation the cells were resuspended in $1 \mathrm{ml}$ PBS and counted by haemocytometer or by DNA estimation, for which a small sample was sonicated. The volume of the cell suspension was adjusted with mixed medium (1:1 of DMEM and Hams F12 (Flow Laboratories)) containing $10 \%$ human serum (Gibco, Paisley, U.K.). The serum was inactivated at $56^{\circ} \mathrm{C}$ for $30 \mathrm{~min}$ and sterilized by passage through a $0.2 \mu \mathrm{m}$ membrane filter.

Cell culture. Cells were added to plastic 24-well culture plates (Costar (Broadway, Cambridge, MA, U.S.A.) and Nunclon (Gibco)) on Day 0 in $500 \mu 1$ medium (1-2 $\times 10^{5}$ cells/well in replicates of 4 wells per treatment). The cells from each patient were cultured separately. Treatments were added to the wells on Day 0 in $100 \mu l$ and the final volume was made up to $1 \mathrm{ml}$ per well with culture medium. Adrenaline bitartrate, noradrenaline bitartrate, propranolol and melatonin were purchased from Sigma (Poole, Dorset, U.K.) and diluted in culture medium at the start of each experiment. Melatonin was added in ethanolic solution, with an equivalent quantity of ethanol $(20 \mathrm{~mm})$ being added to control wells. The hCG used in the culture treatments was standard CR 121 from NIH (Bethesda, MD, U.S.A.) with a biological potency of $13450 \mathrm{IU} / \mathrm{mg}$. The culture plates were incubated at $37^{\circ} \mathrm{C}$ in an humidified incubator $\left(95 \%\right.$ air $\left./ 5 \% \mathrm{CO}_{2}\right)$. Culture media were changed and the treatments renewed every $24 \mathrm{~h}$ for up to 6 days and the samples stored at $-20^{\circ} \mathrm{C}$ until assay.

Assays. Progesterone was measured in the culture media samples using two assays, a direct radioimmunoassay (RIA) kit purchased from RSL Inc (Carson, CA, U.S.A.) and a direct enzymeimmunoassay (EIA) as described by Hodges $e t$ al. (1988). There was a good correlation of progesterone concentrations measured in samples by using the 2 assays over the working range, with a correlation coefficient of $0.94(n=10, P<0.01$; regression slope $=0.78 ; y$ intercept $=0.09 \mathrm{pmol} / \mathrm{ml}$ ). The working range of the RIA was $0.6-65 \mathrm{pmol} / \mathrm{ml}$ with inter- and intra-assay coefficients of $13 \%$ and $7.6 \%$ respectively. The working range for the EIA in culture medium was $0.8-24 \mathrm{pmol} / \mathrm{ml}$ with inter- and intra-assay coefficients of $14 \%$ and $12 \%$ respectively. Samples of uncultured serum-supplemented medium included in each assay showed no detectable progesterone.

Oestradiol-17 $\beta$ was measured in serum samples and culture medium using a direct RIA kit purchased from Sorin Biomedical (Saluggia, Italy). The working range of the assay was $0 \cdot 1-2 \cdot 2 \mathrm{pmol} / \mathrm{ml}$ with inter- and intra-assay coefficients of $7.0 \%$ and $6.0 \%$ respectively.

DNA concentration was measured using the bisbenzimide fluorescence method of Labarca \& Paigen (1980), with calf thymus DNA (Sigma) as standard. Cell number was calculated according to the relationship $1 \mu \mathrm{g}$ DNA $=1.67 \times 10^{5}$ cells.

Statistics. The ability of the treatments to influence cell number was assessed by determining the concentration of DNA after 3 days of culture. As there was no effect of the treatments on cell number the concentrations of progesterone have been normalized for the number of cells present at the start of culture. The data are expressed as mean \pm s.e.m. and analysis of variance (ANOVA) was used to determine statistical significance between control and treatment groups.

\section{Results}

The influence of a range of concentrations of adrenaline and noradrenaline $\left(10^{-7}-10^{-4} \mathrm{M}\right)$ on the production of progesterone by human granulosa cells is shown in Fig. 1. Both adrenaline and 


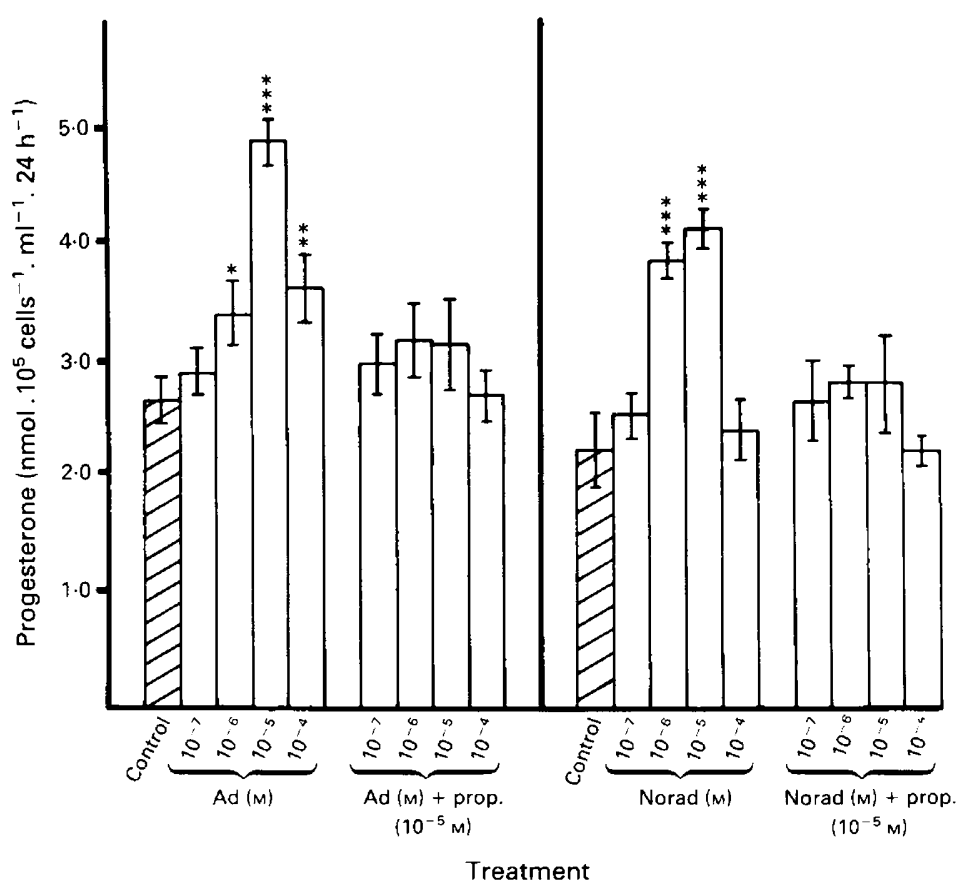

Fig. 1. Concentrations of progesterone produced by human granulosa cells from 2 patients on Day 3 of culture (i.e. between 48 and $72 \mathrm{~h}$ of culture). The cells of one patient were cultured in the presence of a range of concentrations of adrenaline (Ad) and cells from the other patient were cultured with a range of concentrations of noradrenaline (Norad); both treatments were with and without propranolol (prop). Values are mean \pm s.e.m. for 4 replicate wells per treatment. ${ }^{*} P<0.05,{ }^{* *} P<0.01,{ }^{* * *} P<0.001$, compared with control values.

noradrenaline stimulated a dose-related increase in progesterone secretion, the maximum stimulation occurring with a concentration of $10^{-5} \mathrm{M}$. The catecholamines were added from the beginning of the culture and their ability to stimulate progesterone was similar on Days 3 and 4 . Incubation of the cells, with the range of concentrations of adrenaline and noradrenaline, in the presence of propranolol $\left(10^{-5} \mathrm{M}\right)$ prevented the stimulation of progesterone secretion. The response to adrenaline and noradrenaline is shown for cells taken from 2 different patients of 6 giving a similar response.

In a preliminary experiment to determine the dose effect of hCG on progesterone secretion, $1 \mathrm{ng} / \mathrm{ml}$ was found to give a submaximal response whereas 10 and $100 \mathrm{ng} / \mathrm{ml}$ gave similar maximal responses (data not shown). The stimulation of progesterone production by adrenaline $\left(10^{-5} \mathbf{M}\right)$ was compared with the response to $\mathrm{hCG}(100 \mathrm{ng} / \mathrm{ml})$ over 6 days of culture (Fig. 2). There was no effect of either treatment on the first 3 days of culture but adrenaline and hCG stimulated progesterone secretion on Day 4 and thereafter. Control concentrations of progesterone declined from Day 4 to Day 6 but the degree of stimulation ( $\sim 2$-fold) remained constant. The degrees of stimulation were similar for adrenaline and hCG during continuous treatment over the 6 days of culture. Incubation with adrenaline $\left(10^{-5} \mathrm{M}\right)$ and hCG $(10 \mathrm{ng} / \mathrm{ml})$ together and compared with each treatment alone, on Days 3 and 4 of culture, is shown in Fig. 3. There was no further stimulation of progesterone when the two treatments were added together. Adrenaline had no effect on oestradiolI7 $\beta$ production in this experiment (results not shown).

The degree of stimulation of progesterone production by adrenaline varied between patients (Table 1). Of the 8 patients studied, 6 showed a response to adrenaline whereas there was no effect in 2 patients. A similar variation in response occurred with melatonin (Table 1). 


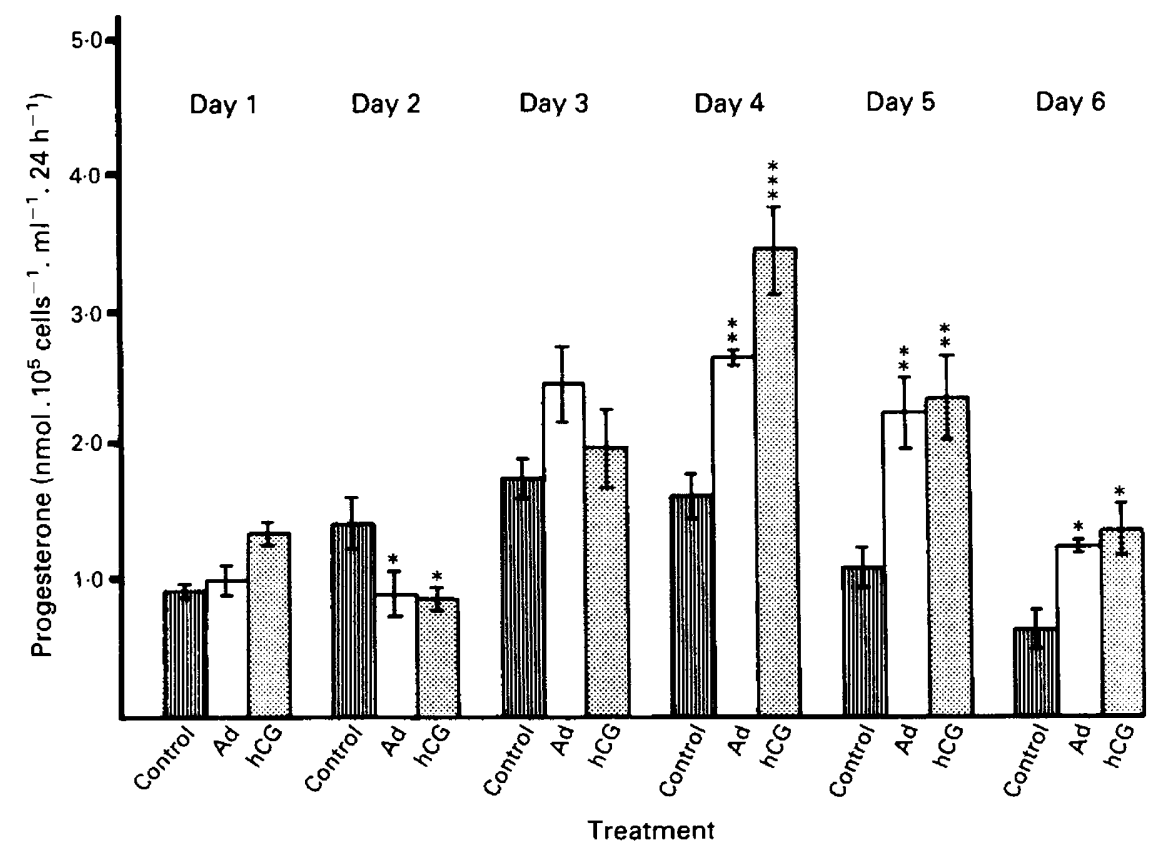

Fig. 2. Concentrations of progesterone from human granulosa cells in culture medium changed every $24 \mathrm{~h}$ over 6 days in the presence of adrenaline (Ad, $\left.10^{-5} \mathrm{M}\right)$ and $\mathrm{hCG}(100 \mathrm{ng} / \mathrm{ml})$. Values are mean \pm s.e.m. for 4 replicate wells per treatment. ${ }^{*} P<0.05,{ }^{* *} P<0.01,{ }^{* * *} P<0.001$, compared with control values.

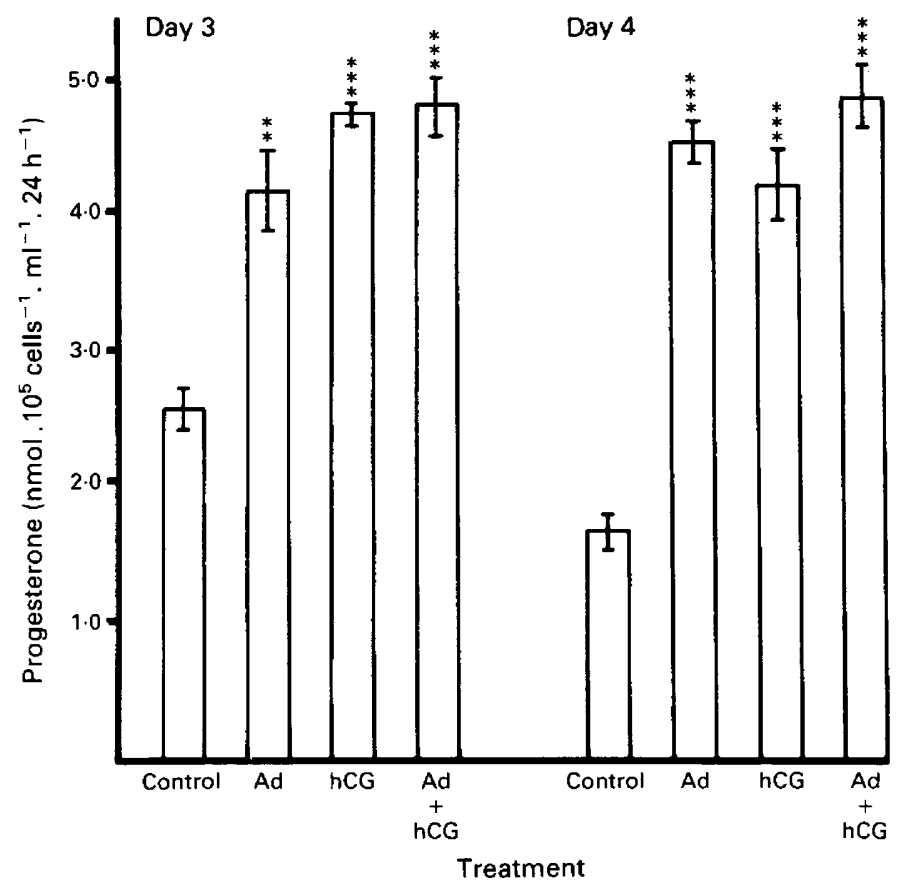

Fig. 3. Concentrations of progesterone from human granulosa cells on Days 3 and 4 of culture in the presence of adrenaline (Ad) $\left(10^{-5} \mathrm{M}\right)$ and $\mathrm{hCG}(10 \mathrm{ng} / \mathrm{ml})$. Values are mean \pm s.e.m. for 4 replicate wells per treatment. ${ }^{*} P<0.05,{ }^{* *} P<0.01,{ }^{* * *} P<0.001$, compared with control values. 
Table 1. Concentrations of progesterone produced by granulosa cells from 13 patients on Day 3 or 4 of culture in the presence of melatonin $(200 \mathrm{pg} / \mathrm{ml})$ or adrenaline $\left(10^{-5} \mathrm{M}\right)$ and the percentage difference between the control and treatment wells

\begin{tabular}{|c|c|c|c|c|}
\hline \multirow{2}{*}{$\begin{array}{l}\text { Patient } \\
\text { no. }\end{array}$} & \multicolumn{3}{|c|}{$\begin{array}{c}\text { Progesterone } \\
\left(\mathrm{nmol} .10^{5} \mathrm{cells}^{-1} \cdot \mathrm{ml}^{-1} \cdot 24 \mathrm{~h}^{-1}\right)\end{array}$} & \multirow{2}{*}{$\begin{array}{c}\% \\
\text { Difference }\end{array}$} \\
\hline & Control & Melatonin & & \\
\hline 1 & $1.93 \pm 0.33$ & $4.62 \pm 0.32$ & $* * *$ & 231 \\
\hline 2 & $0.76 \pm 0.03$ & $1.35 \pm 0.11$ & $* * *$ & 177 \\
\hline 3 & $1.91 \pm 0.13$ & $1.62 \pm 0.16$ & & 85 \\
\hline 4 & $3.09 \pm 0.35$ & $3.95 \pm 0.19$ & & 128 \\
\hline 5 & $1.31 \pm 0.13$ & $2 \cdot 11 \pm 0.12$ & $* *$ & 161 \\
\hline 6 & $2 \cdot 20 \pm 0.18$ & $3.28 \pm 0.22$ & ** & 149 \\
\hline 7 & $2.56 \pm 0.14$ & $4.36 \pm 0.38$ & $* * *$ & 183 \\
\hline & Control & Adrenaline & & \\
\hline 6 & $2.20 \pm 0.18$ & $3 \cdot 12 \pm 0 \cdot 09$ & $* * *$ & 142 \\
\hline 7 & $2.56 \pm 0.14$ & $3.98 \pm 0.38$ & ** & 156 \\
\hline 8 & $1.82 \pm 0.13$ & $1.99 \pm 0.08$ & & 110 \\
\hline 9 & $2.64 \pm 0.22$ & $4.90 \pm 0 \cdot 10$ & $* * *$ & 186 \\
\hline 10 & $1.99 \pm 0.11$ & $1.65 \pm 0.06$ & & 83 \\
\hline 11 & $1.62 \pm 0.15$ & $2.64 \pm 0.06$ & $* * *$ & 163 \\
\hline 12 & $1.69 \pm 0.27$ & $2.91 \pm 0.36$ & * & 173 \\
\hline 13 & $2.40 \pm 0.37$ & $4 \cdot 20 \pm 0.11$ & $* * *$ & 175 \\
\hline
\end{tabular}

Values are mean \pm s.e.m., $n=4$.

${ }^{*} P<0 \cdot 05,{ }^{* *} P<0.01,{ }^{* * *} P<0.001$, compared with control values.

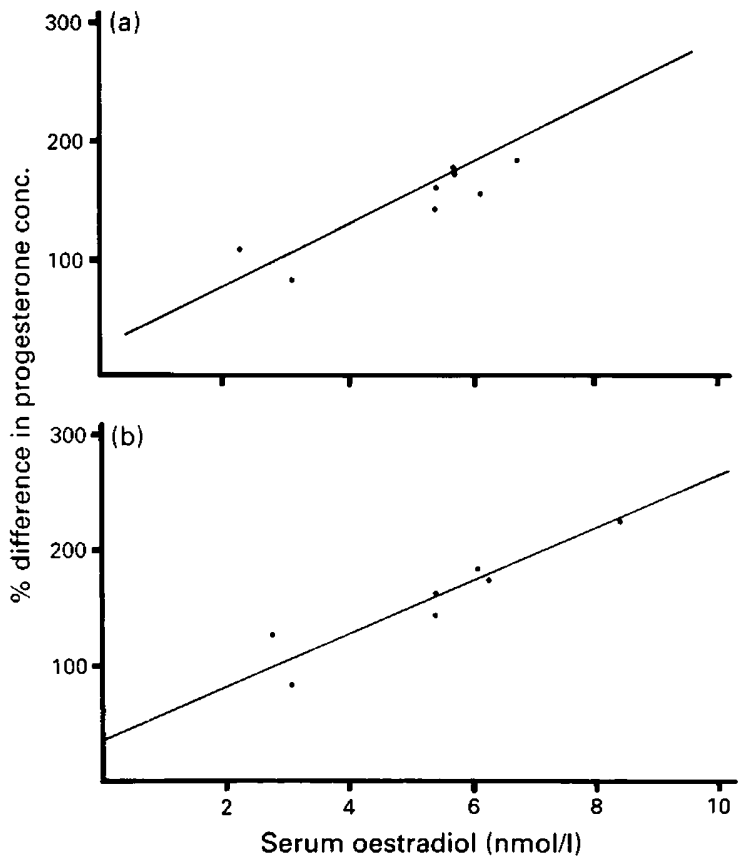

Fig. 4. The degree of stimulation of progesterone is shown as the percentage difference between progesterone concentrations measured in control wells and in (a) the presence of adrenaline $\left(10^{-5} \mathrm{M}\right)$ and in (b) the presence of melatonin $(200 \mathrm{pg} / \mathrm{ml})$, plotted against the concentrations of oestradiol-17ß in the serum of the patients on the day on which the granulosa cells were aspirated. 


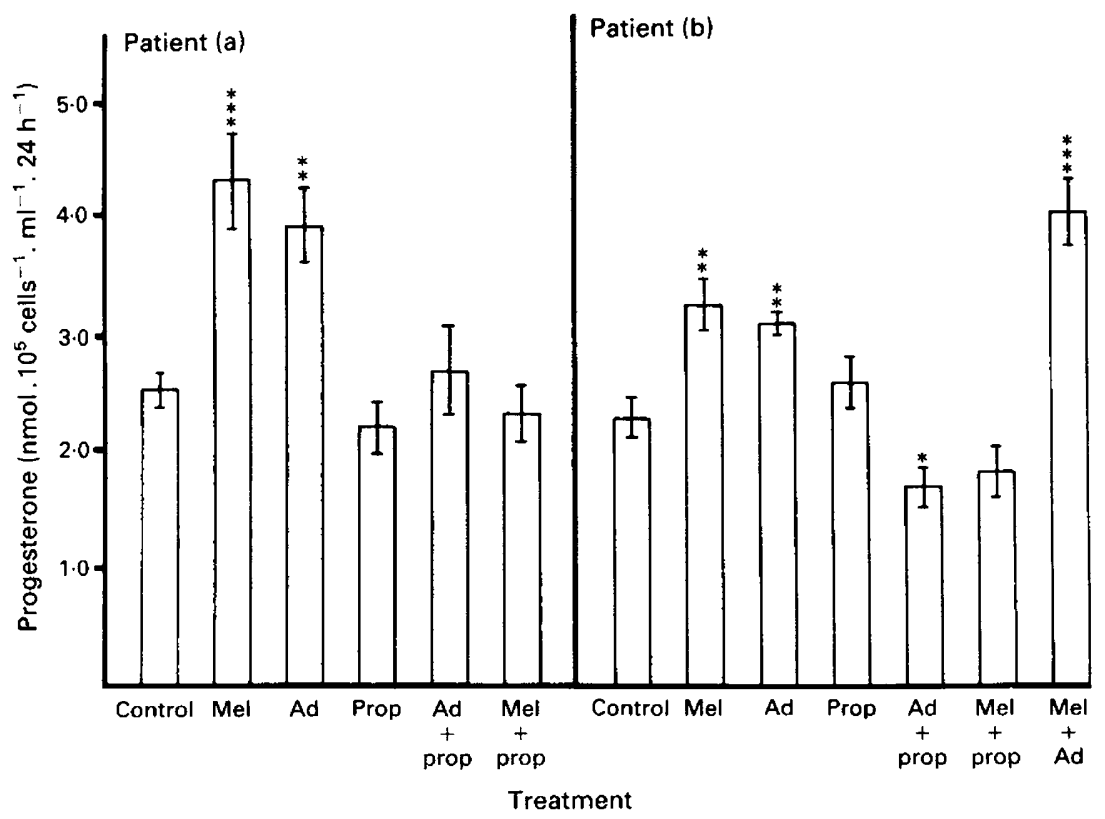

Fig. 5. Concentrations of progesterone produced by granulosa cells from 2 patients with comparatively high oestradiol $-17 \beta$ concentrations (Patient $a=6.05 \mathrm{nmol} / 1$, Patient $b=5.33 \mathrm{nmol} / 1$ in the presence of melatonin (Mel) $(200 \mathrm{pg} / \mathrm{ml})$, adrenaline (Ad) $\left(10^{-5} \mathrm{M}\right)$, and propranolol (prop) $\left(10^{-5} \mathrm{M}\right)$. Values are mean \pm s.e.m. for 4 replicated wells per treatment. ${ }^{*} P<0 \cdot 05$, ${ }^{* *} P<0 \cdot 01,{ }^{* * *} P<0 \cdot 001$, compared with control values.

A significant correlation was found between the degree of stimulation of progesterone by adrenaline $(r=0.9, \mathrm{~N}=8, P<0.05)$ (Fig. 4a) or melatonin $(r=0.94, \mathrm{~N}=7, P<0.01)$ (Fig. 4b) and the circulating oestradiol-17 $\beta$ concentration on the day of follicular puncture. High serum oestradiol concentrations were associated with a large stimulation of progesterone by adrenaline and melatonin. The serum concentration of oestradiol was significantly correlated $(r=0.93, n=7$, $P<0.01$ ) with the total follicular fluid concentration and there was no correlation with the number of follicles. No differences were apparent between cells taken from patients in the two clinics or between the different regimens of clomiphene or hMG stimulation.

The effects of melatonin and adrenaline were further compared in 2 patients (one from each clinic) with comparatively high serum oestradiol concentrations (Fig. 5). In both patients melatonin and adrenaline significantly stimulated progesterone secretion. Melatonin and adrenaline added together (in Patient b) exerted a synergistic effect. Propranolol had no effect on progesterone secretion but it did prevent the stimulations seen with adrenaline and melatonin.

\section{Discussion}

This study describes for the first time the stimulatory effects of adrenaline and noradrenaline on progesterone production by human granulosa cells cultured in the presence of serum. The response was similar to that elicited by hCG in both time course and extent. Melatonin stimulated progesterone production and the degree of stimulation by melatonin and adrenaline was dependent on the concentration of oestrogen produced by the follicles at the time of follicular puncture. The response to melatonin and adrenaline was blocked by the $\beta$-receptor antagonist, propranolol. 
In any study of this nature, the interpretation of results depends on a number of assumptions. Firstly, data for progesterone production have been expressed in terms of concentration per cell number at the start of culture and it has been assumed that the numbers remained the same during the culture period and were not affected by the treatments. This is justified as human granulosa cells cultured in serum do not proliferate or only do so very slowly during the first 6 days of culture (Tapanainen et al., 1987) and the treatments were found to have no effect on cell number after 3 days of culture. Secondly, it is assumed that the cells have undergone a process of luteinization in culture and that the changes in morphology of the cells and the secretion of progesterone are characteristics of the luteinization which occurs in parallel in vivo and in vitro (Crisp \& Channing, 1972; Tureck \& Strauss, 1982). A further assumption is that the cells have not been affected by treatment with clomiphene, $\mathrm{hMG}$ and $\mathrm{hCG}$ beyond their physiological response to gonadotrophins in the normal cycle, as reflected by their production of oestradiol-17 $\beta$ at the time of collection.

The discrepancy in the reported effects of catecholamines on the human corpus luteum (see 'Introduction') may be in the nature of the preparations studied; dispersed luteal cells are unresponsive, whereas slices are stimulated. Whether this difference reflects absence of intercellular signals which are disrupted by cell dispersion, or the loss of receptors during dispersion, is uncertain. As the granulosa cells studied here appeared to undergo luteinization in culture, it is possible that the ability of the cells to respond to catecholamines resulted from the process of luteinization.

Certain characteristics of the stimulation of progesterone production by adrenaline and hCG were similar. The human granulosa cell in the present study is therefore like the rat luteal cell (Harwood et al., 1980) in that both cells respond to hCG and adrenaline but there is no additive effect on progesterone secretion. It was suggested from studies in the rat that catecholamines and hCG act via independent receptor systems to stimulate a common pool of adenylate cyclase (Richardson, 1986). In contrast, the response of human granulosa cells to the $\beta$-adrenergic agonist, isoproteronol, and to hCG in the study of Hillensjo et al. (1985) was rather different with isoproterenol having no effect alone but enhancing the action of hCG. The inability of the granulosa cells to respond before Day 4 of culture agrees with previous studies in which granulosa cells taken from the follicles of patients exposed to a preovulatory injection of hCG could not be stimulated with hCG during the first 2-4 days of culture (Schmidt et al., 1984; Hillensjo et al., 1985; Tapanainen et al., 1987). Tapanainen et al. (1987) suggest that the cells were already maximally stimulated in vivo by hCG and could not be stimulated further in vitro. Since the cells in culture were continually exposed to hCG the attainment of response by Day 4 of culture may instead represent a maturation process. This could be similar to the changes which occur to the corpus luteum in vivo; hCG had no effect on progesterone production by early human luteal tissue (up to 4 days after the LH peak) whereas it stimulated production by mid-luteal tissue (Vega et al., 1987).

Granulosa cell responses to adrenaline and melatonin correlated with circulating oestradiol concentrations which were indicative of total follicular oestradiol production. High concentrations of oestradiol in follicular fluid have been shown to be associated with mature follicles containing oocytes which have a greater ability to fertilize in vitro (McNatty et al., 1979; Bomsel-Helmreich et al., 1979). In the rat ovary, $\beta$-adrenergic receptors change with the stage of the oestrous cycle and are correlated with serum oestradiol concentrations (Jordan, 1981). It therefore appears likely that oestradiol stimulates the development of $\beta$-adrenergic receptors as an important part of follicular function.

Webley \& Leidenberger (1987) have shown an increase in the circadian output of melatonin during the luteal phase of the menstrual cycle and demonstrated the ability of melatonin to increase the production of progesterone by the corpus luteum of the marmoset monkey perfused in vivo (Webley \& Hearn, 1987; Hearn \& Webley, 1987). The mechanism by which melatonin acts centrally or peripherally is as yet unknown. In the present study the responses of human granulosa cells to adrenaline and melatonin were similar in that they were both dependent on the degree of follicular development, as represented by peripheral oestradiol concentrations. In addition the $\beta$-receptor antagonist propranolol blocked the stimulation of progesterone by both adrenaline and melatonin. 
Melatonin, at physiological concentrations, increases the binding of $\beta$-adrenergic agonists by pineal tissue in vitro (Sweat, 1986), perhaps indicating the mechanism by which it acts, but melatonin was also active in stimulating progesterone secretion by human granulosa cells in the absence of added catecholamines, suggesting an additional mechanism. The inhibition of the action of melatonin by propranolol indicates that melatonin may be acting on a $\beta$-receptor.

The ovary has a rich autonomic innervation (Burden, 1985) and catecholamines may also reach the ovary via the peripheral circulation. Melatonin is present in the follicular fluid of preovulatory follicles and at higher concentrations than in the corresponding peripheral circulation (Brzezinski $e t$ al., 1987). Propranolol infused in vivo in the ovary or the peripheral circulation resulted in decreased circulating progesterone concentrations during the luteal phase in the anaesthetized cat (Wheeler $e t$ al., 1987) and the sheep (Wheeler et al., 1988). These results suggest a dependence, to a degree, of progesterone on the sympathetic nervous system. The results presented here further suggest that catecholamines and melatonin may have a physiological role in modulating luteal function.

We thank Vera Baukloh, for collecting the human granulosa cells; Mr P. R. Brinsden and Alison Shephard for samples from the Humana Hospital, Wellington; Alexandra Given and Cornelia Praetorius for expert technical assistance; Professor F. A. Leidenberger for support; and Professor A. P. F. Flint for comments on the manuscript. This work was funded by a joint MRC/AFRC programme grant (to J.P.H.) and partial support through a project grant from the World Health Organisation, Special Programme of Research, Development and Research Training in Human Reproduction (WHO-HRP) and a grant (No. 0706506/9) from the Bundesministerium fur Forschung and Technologie.

\section{References}

Battista, P.J., Poff, J.P., Deaver, D.R. \& Condon, W.A. (1987) Biogenic amine regulation of bovine luteal progesterone production in vivo. J. Reprod. Fert. 80, 517-522.

Bennegard, B., Dennefors, B. \& Hamberger, L. (1984) Interaction between catecholamines and prostaglandin $\mathrm{F}_{2 a}$ in human luteolysis. Acta endocr., Copenh. $106,532-537$.

Bomsel-Helmreich, O., Gougeon, A., Thebault, A., Saltarelli, D., Milgrom, E., Frydman, R. \& Papiernick, E. (1979) Healthy and atretic human follicles in the preovulatory phase: differences in evolution of follicular morphology and steroid content of follicular fluid. J. clin. Endocr. Metab. 48, 686-695.

Brzezinski, A., Seibel, M.M., Lynch, H.J., Deng, M. \& Wurtman, R.J. (1987) Melatonin in human preovulatory follicular fluid. J. Clin. Endocr. Metab. 64, $865-867$.

Burden, H.W. (1978) Ovarian innervation. In The Vertebrate Ovary, pp. 615-638. Ed. R. E. Jones. Plenum Press, New York.

Casper, R.F. \& Cotterell, M.A. (1984) The effect of adrenergic and cholinergic agents on progesterone production by human corpus luteum in vitro. Am. J. Obstet. Gynecol. 148, 663-669.

Condon, W.A. \& Black, D.L. (1976) Catecholamineinduced stimulation of progesterone by the bovine corpus luteum in vitro. Biol. Reprod. 15, 573-578.

Crisp, T.M. \& Channing, C.P. (1972) Fine structural events correlated with progesterone secretion during luteinization of rhesus monkey granulosa cells in culture. Biol. Reprod. 7, 55-72.
Eyster, K.M. \& Stouffer, R.L. (1985) Adenylate cyclase in the corpus luteum of the rhesus monkey. II. Sensitivity to nucleotides, gonadotrophins, catecholamines and nonhormonal activators. Endocrinology 116, 1552-1558.

Fraser, H.M., Baird, D.T., McRae, G.I., Nestor, J.J. \& Vickery, B.H. (1985) Suppression of luteal progesterone secretion in the stumptailed macaque by an antagonist analogue of luteinising hormone-releasing hormone. J. Endocr. 104, R1-R4.

Fraser, H.M., Abbott, M., Laird, N.C., McNeilly, A.S., Nestor, J.J. \& Vickery, B.H. (1986) Effects of an LHRH antagonist on the secretion of LH, FSH, prolactin and ovarian steroids at different stages of the luteal phase in the stumptailed macaque (Macaca arctoides). J. Endocr. 111, 83-89.

Harwood, J.P., Richert, N.D., Dufau, M.L. \& Catt, K.J. (1980) Gonadotrophin-induced desensitization of epinephrine action in the luteinized rat ovary. Endocrinology 107, 280-288.

Hearn, J.P. \& Webley, G.E. (1987) Regulation of the corpus luteum of early pregnancy in the marmoset monkey: local interactions of luteotrophic and luteolytic hormones in vivo and their effects on the secretion of progesterone. J. Endocr. 114, 231-239.

Hillensjo, T., Sjogren, A., Strander, B., Nilsson, L., Wikland, M., Hamberger, L. \& Roos, P. (1985) Effect of gonadotrophins on progesterone secretion by cultured granulosa cells obtained from human preovulatory follicles. Acta endocr., Copenh. 110, $401-407$.

Hodges, J.K., Green, D.I., Cottingham, P.G., Sauer, M.J., 
Edwards, C. \& Lightman, S.L. (1988) Induction of luteal regression in the marmoset monkey (Callithrix jacchus) by a gonadotrophin-releasing hormone antagonist and the effects on subsequent follicular development. J. Reprod. Fert. 82, 743-752.

Jordan, A.W. (1981) Changes in ovarian $\beta$-adrenergic receptors during the estrous cycle of the rat. Biol. Reprod. 24, 245-248.

Jordan, A.W., Caffrey, J.L. \& Niswender, G.D. (1978) Catecholamine-induced stimulation of progesterone and adenosine $3^{\prime}, 5^{\prime}$-monophosphate production by dispersed ovine luteal cells. Endocrinology 103, 385-392.

Knobil, F. (1973) On the regulation of the primate corpus luteum. Biol. Reprod. 8, 246-258.

Labarca, C. \& Paigen, K. (1980) A simple, rapid and sensitive DNA procedure. Analyt. Biochem. 102, 344-352.

Luck, M.R. \& Jungclas, B. (1987) Catecholamines and ascorbic acid as stimulators of bovine ovarian oxytocin secretion. J. Endocr. 114, 423-430.

Luck, M.R. \& Jungclas, B. (1988) The time-course of oxytocin secretion from cultured bovine granulosa cells, stimulated by ascorbate and catecholamines. $J$. Endocr. 116, 247-258.

MeNatty, K.P., Smith, D.M., Makris, A., Osathanondh, R. \& Ryan, K.J. (1979) The microenvironment of the human antral follicle: interrelationships among the steroid levels in antral fluid, the population of granulosa cells, and the status of the oocyte in vivo and in vitro. J. clin. Endocr. Metab. 49, 851-860.

Norjavaara, E., Selstam, G. \& Ahren, K. (1982) Catecholamine stimulation of cyclic AMP and progesterone production in rat corpora lutea of different ages. Acta endocr., Copenh. 100, 613-622.

Ratner, A., Sanborn, C.R. \& Weiss, G.K. (1980) $\beta$ adrenergic stimulation of cAMP and progesterone in rat ovarian tissue. Am. J. Physiol. 239, E139-El43.

Richardson, M.C. (1986) Hormonal control of ovarian luteal cells. Oxford Rev. Reprod. Biol. 8, 321-378.

Richardson, M.C. \& Masson, G.M. (1980) Progesterone production by dispersed cells from human corpus luteum: stimulation by gonadotrophins and prostaglandin $F-2$ lack of response to adrenaline and isoprenaline. J. Endocr. 87, 247-254.

Ross, G.T. (1979) Human chorionic gonadotrophin and maternal recognition of pregnancy. In Maternal Recognition of Pregnancy (Ciba Fdn. Symp. No. 64), pp. 377-395. Excerpta Medica, Amsterdam.
Schmidt, C.L., Kendall, J.Z., Dandekar, P.V., Quigley, M.M. \& Schmidt, K.L. (1984) Characterization of long-term monolayer cultures of human granulosa cells from follicles of different size and exposed in vivo to clomiphene citrate and hCG. J. Reprod. Fert. 71, 279-287.

Sweat, F.W. (1986) Beta-adrenergic binding is increased by melatonin and alpha-adrenergic compounds. Biochem. Biophys. Res. Commun. 138, 1196-1202.

Tapanainen, J., Yamamoto, M., Leinonen, P.J., Jaffe, R.B. \& Tapanainen, P. (1987) Regulation of human granulosa-luteal cell progesterone production and proliferation by gonadotropins and growth factors. Fert. Steril. 48, 576-580.

Tureck, R.W. \& Strauss, J.F., III (1982) Progesterone synthesis by luteinized human granulosa cells in culture: the role of de novo sterol synthesis and lipoprotein-carried sterol. J. clin. Endocr. Metab. 54, 367-373.

Vega, M., Devoto, L., Navarro, V., Castro, O. \& Kohen, P. (1987) In vitro net progesterone production by human corpora lutea: effects of human chorionic gonadotropin, dibutyryl adenosine 3',5'-monophosphate, cholera toxin and Forskolin. J. clin. Endocr. Metab. 65, 747-752.

Webley, G.E. \& Hearn, J.P. (1987) Local production of progesterone by the corpus luteum of the marmoset monkey in response to perfusion with chorionic gonadotrophin and melatonin in vivo. J. Endocr. 112, 449-457.

Webley, G.E. \& Leidenberger, F.A. (1986) The circadian pattern of melatonin and its positive relationship with progesterone in women. J. clin. Endocr. Metab. 63, 323-328.

Webley, G.E. \& Luck, M.R. (1986) Melatonin directly stimulates the secretion of progesterone by human and bovine granulosa cells luteinized in vitro. $J$. Reprod. Fert. 78, 711-717.

Wheeler, A.G., Walker, M. \& Lean, J. (1987) Influence of adrenergic receptors on ovarian progesterone secretion in the pseudopregnant cat and oestradiol secretion in the oestrous cat. J. Reprod. Fert. 79, 195-205.

Wheeler, A.G., Lean, J. \& Walker, M. (1988) Peripheral progesterone concentrations in the luteal-phase ewe: effects of a $\beta$-adrenergic receptor antagonist and two $\beta_{2}$-adrenergic agonists. J. Endocr. 116, 137-142.

Received 25 April 1988 